\title{
Trote Universitário: Vivências e Trabalhos em Busca da Humanização na Recepção aos Primeiranistas
}

\author{
Damiano, Rodolfo Furlan; Santos, Amanda Guedes dos; \\ Almeida Júnior, Antônio R. de \\ Pontifícia Universidade Católica de São Paulo — damianorf@gmail.com
}

Introdução o trote universitário e as marcas de sua violência acompanham a sociedade brasileira há muito tempo, espalhando-se por muitas universidades do país. Há um recente interesse científico pelo assunto, mas ainda se dá pouca atenção ao estudo de suas bases e consequências de longo prazo. As ações que visem coibir a prática de seus abusos também são negligenciadas pela ciência brasileira. com base em um processo de humanização, educativo e do estímulo ao senso crítico, alguns alunos do segundo e terceiro anos de medicina propuseram à direção da faculdade em 2013 a criação do Grupo de Apoio ao Primeiranista (GAP). o GAP tem como objetivo humanizar a recepção dos ingressantes e, para isto, realizou durante o ano de 2013 atividades visando a educação e a coibição do trote na universidade. Objetivos Relatar criticamente a experiência do GAP na vivência e enfrentamento do trote universitário. Métodos Trata-se de um relato de experiência no qual se busca pontuar as vivências, atividades e dificuldades enfrentadas pelo GAP durante os projetos desenvolvidos em 2013 com foco no trote universitário. Resultados Após a identificação do trote como um problema enfrentado pelos ingressantes que adentram a universidade e a estruturação de um grupo para auxiliá-los nesta nova fase da vida, iniciou-se a estruturação de atividades que visassem o apoio psicológico e social ao ingressante que está passando por dificuldades nessa fase de transição. para o apoio psicológico foram realizadas reuniões semanais com base no mentoring, nas quais os ingressantes puderam se apoiar na vivência dos discentes que já passaram por tal transição, para que pudessem superar seus problemas e dúvidas, além de identificarem opções para quem busca uma universidade mais humana. Durante estas reuniões ficou evidente a necessidade de se estruturar uma intervenção para discutir cientificamente o trote na universidade. para isso foi organizado um simpósio intitulado: "I Simpósio Anatomia do Trote" com a participação de 100 discentes, onde foram discutidas as bases psicológicas, sociológicas, jurídicas e institucionais do trote. Conclusões As atividades desenvolvidas pelo GAP no ano de 2013 mostraram-se muito relevantes e contribuíram no processo de humanização da universidade. Algumas dificuldades foram encontradas como a falta de bases científicas no estudo do fenômeno do trote, a falta de preparo dos alunos para organizar uma discussão em âmbito social universitário e a represália por parte dos que defendem o fenômeno do trote, docentes e discentes. o trote universitário deve ser entendido como uma manifestação de violência e devem-se propor grupos que acolham o ingressante nessa fase e proponham novas formas de integração na universidade.

Damiano, Rodolfo Furlan; Santos, Amanda Guedes dos; Almeida Júnior, Antônio R. de. Trote Universitário: Vivências e Trabalhos em Busca da Humanização na Recepção aos Primeiranistas. In: Anais do Congresso Internacional de Humanidades \& Humanização em Saúde [= Blucher Medical Proceedings, num.2, vol.1]. São Paulo: Editora Blucher, 2014. ISSN 2357-7282

DOI 10.5151/medpro-cihhs-10177 